\title{
REGULATION OF BLOOD LEVELS OF LH IN BULLS: INFLUENCE OF AGE, BREED, SEXUAL STIMULATION AND TEMPORAL FLUCTUATIONS
}

\author{
S. GOMBE, * W. C. HALL, K. MaENTEE, W. HANSEL AND \\ B. W. PICKETT $\dagger$ \\ Department of Animal Science, N.Y.S. College of Agriculture, \\ Cornell University, Ithaca, N.Y. 14850, U.S.A.
}

(Received 13th November 1972)

\begin{abstract}
Summary. Histological studies of adenohypophyses of male Friesian and Ayrshire calves, aged 1 to 2 months, and measurements of plasma or serum LH by solid phase radioimmunoassay in Angus, Holstein, Guernsey and Jersey bulls, ranging in age from 7 months to 2 years were carried out to determine factors influencing gonadotrophin secretion. The gonadotrophin-secreting delta cells constituted $3 \%$ of the cell population of the cortical region of the adenohypophyses at 1 month of age and $4 \%$ at 2 months of age. Considerable quantities of $\mathrm{LH}(3 \cdot 7 \pm 0.3 \mathrm{ng} / \mathrm{ml})$ were present in plasma samples of Angus bulls at 7 to 9 months of age. The levels rose to $4 \cdot 3 \pm 1 \cdot 1 \mathrm{ng} / \mathrm{ml}$ at 12 to 14 months and, at 2 or more years of age, basal LH values were of the order of 7 to $10 \mathrm{ng} / \mathrm{ml}$ plasma or serum. No breed differences were noted either in pituitary histology or LH concentrations.

Teasing and ejaculations caused no increase in serum $\mathrm{LH}$ values for up to $3 \mathrm{hr}$ after sexual excitement, irrespective of whether a bull or an oestrous cow was the teaser. Large irregularly occurring daily fluctuations in serum LH (0 to $50 \mathrm{ng} / \mathrm{ml}$ ) were found in 6-year-old Holstein bulls. Similar but smaller variations ( 1 to $16 \mathrm{ng} / \mathrm{ml}$ plasma) were found in the younger Angus bulls aged 7 to 14 months. A distinct 24-hr variation in serum LH was found in two Holstein and two Guernsey bulls aged $1 \frac{1}{2}$ to 2 years. The diurnal serum LH values were twice the nocturnal values, an abrupt change-over occurring at 18.00 hours when most of the bulls were lying down. Hourly variations were small and insignificant during the morning and afternoon.
\end{abstract}

\section{INTRODUGTION}

Few studies have been done on gonadotrophin secretion in cattle. Jubb \& McEntee (1955), using PAS-Orange G staining technique, showed that delta

\footnotetext{
* Present address: Department of Animal Physiology, University of Nairobi, P.O. Box 30197, Nairobi, Kenya.

$\dagger$ Present address: Animal Production Laboratory, Colorado State University, Fort Collins, Colorado 80521, U.S.A.
} 
basophils are the gonadotrophin-secreting cells in cattle. This was confirmed by Simmons, Cochrane \& Pomerantz (1970) who employed both periodic acid Schiff (PAS)-Orange G and fluorescent antibody staining techniques. However, neither Jubb \& McEntee (1955) nor Simmons et al. (1970) reported on when the cells occurred. Simmons et al. (1970) showed that the intensity of fluorescence of delta cells was more closely correlated with the release of LH from delta cells during oestrous cycles of dairy cows than was the intensity of PAS-positive material. In boys, Swanson \& Ezrin (1960) demonstrated the presence of delta cells by 10 years of age and the numbers gradually increased until puberty was reached. This work has been corroborated by the recent measurements of LH and FSH in the blood plasma of boys and girls. Burr, Sizonenko, Kaplan \& Grumbach (1970), Pichurova (1970), Sizonenko, Burr, Kaplan \& Grumbach $(1969,1970)$, Yen \& Vicic (1970) and Buckler \& Clayton (1971) all clearly showed the presence of gonadotrophins in plasma before puberty, and their gradual increase until puberty was reached.

Dunn \& McEntee (1964) recorded a higher incidence of hormone-dependent testicular tumours in Guernsey bulls compared to Holsteins or Jerseys, suggesting that breed differences may exist in plasma gonadotrophin levels.

Recently, Katongole, Naftolin \& Short (1971) reported increases in plasma LH in 8-year-old Friesian bulls following teasing with an oestrous cow.

The present study was carried out to examine some of the parameters that might influence gonadotrophin activity in bulls.

\section{MATERIALS AND METHODS}

\section{Influence of age}

This study involved two phases and two different techniques. In the first phase, cytological examination of the adenohypophyses of bull calves (sixteen Friesian and sixteen Ayrshire) aged 1 to 2 months and local zebu bulls (ten Grade Boran and ten Masai Boran) aged $1 \frac{1}{2}$ to 8 years was carried out using the PAS-Orange G staining technique. In the second phase, plasma/serum LH levels were determined by solid phase radioimmunoassay, as modified by Hobson \& Hansel (1972), in four breeds of bulls ranging in age from 7 months to 12 years. The adenohypophyses were obtained within $40 \mathrm{~min}$ of slaughter and immediately immersed in cold Zenker's solution for fixation. After $48 \mathrm{hr}$, the glands were processed, sectioned at $5 \mu \mathrm{m}$ and stained by PAS-Orange G. The mid-sagittal delta cell population of the cortex and medulla was determined under high power $(\times 970)$. The cell nuclei diameters were measured by an ocular micrometer and representative photomicrographs were taken.

Plasma or serum samples used for LH measurements were obtained partly from experimental bulls maintained at Colorado State University, and partly from another herd maintained at New York State Veterinary College at Cornell. The Colorado bulls comprised twenty-two Angus bulls aged 7 to 9 months at the beginning of a feeding experiment which lasted 5 months; half the bulls being maintained at 133\% National Research Council (NRC) requirements and the other half at $95 \% \mathrm{NRC}$ requirements. The bulls were bled by venepuncture every 2 weeks for 5 months, at the end of which time an 
electroejaculate was collected and they were slaughtered. It was subsequently shown that the plasma LH values of both groups did not differ at the beginning and at the end of the experiment. Values given in the paper for these two periods are, therefore, the means for the twenty-two animals.

The Cornell bulls were always bled by the same person (W.C.H.) in order to avoid any possible influence of stress caused by strangers in the pens. Samples were obtained by jugular venepuncture, cooled overnight at $4^{\circ} \mathrm{C}$ then centrifuged to obtain the sera which were kept frozen until required for LH analysis.

\section{Influence of breed}

Serum samples used for this portion of the study were obtained from an artificial insemination herd at Cornell and comprised eleven Holstein bulls, seven Guernseys, and three Jerseys ranging in age from 2 to 12 years. Plasma samples from the twenty-two Colorado bulls became available later in the study. Because of the paucity of numbers, the animals were grouped into five age groups for the purpose of comparison, as indicated in Text-fig. 2.

\section{Influence of sexual stimulation}

Four bulls, two Holsteins and two Guernseys, aged $1 \frac{1}{2}$ to 2 years were used in this study, with a fifth bull used as a teaser. Thirty minutes before sexual stimulation, each bull was bled in its pen by jugular venepuncture. It was then presented to the teaser bull and allowed to make two incomplete mounts before intromission and ejaculation into an artificial vagina. The bull was led back into its stall and bled at $\frac{1}{2}, 1,2$ and $3 \mathrm{hr}$ after ejaculation. After a 4-day rest period, the procedure was repeated.

Six weeks later, two of the bulls were teased with an oestrous cow. In this instance, blood samples were obtained beginning at $2 \mathrm{hr}$ before sexual stimulation. Blood was also collected immediately after, and $\frac{1}{2}, 1$ and $2 \mathrm{hr}$ after ejaculation.

\section{Temporal fluctuations}

Measurements of LH in plasma samples obtained from young Angus bulls at intervals of 2 weeks over a 5-month period revealed large fluctuations in the values for individual bulls. To determine whether these fluctuations were rhythmic, three Holstein bulls aged 6 years were bled daily for two periods of 1 month each. Later, hourly blood samples were collected from two Holsteins and two Guernseys aged $1 \frac{1}{2}$ to 2 years for two periods of $24 \mathrm{hr}$ each to check on the possible occurrence of circadian variation. The same animals were bled on separate occasions every $10 \mathrm{~min}$ for $1 \mathrm{hr}$ and $2 \mathrm{hr}$, respectively, to determine whether there were rapid fluctuations in plasma $\mathrm{LH}$ values.

\section{RESULTS}

\section{Influence of age}

Cytological studies revealed that delta cells were present in the adenohypophyses of well nourished calves at 1 month of age. Three of the thirty-two calves examined were in poor nutritional condition and no delta cells were found in 
these animals. Instead, small round cells with darkly staining nuclei and very little cytoplasm were found. Their numbers decreased with age, concomitant with an increase in the number of delta cells. In 1-month-old calves, the delta cells constituted $3 \%$ of the cell population of the cortical area of the adenohypophyses; by 2 months of age, this figure had increased to $4 \%$. Unlike adult delta cells, however, the cytoplasm of the calf cells was finely granular and stained less intensely with PAS.

The cortical delta cell population of poorly nourished Masai Boran bulls aged $1 \frac{1}{2}$ years was only $4 \%$ compared to 6 to $8 \%$ in well nourished Grade Borans of similar age. By 3 years of age, however, even the poorly nourished bulls had a cortical delta cell population of 6 to $8 \%$. The delta cells were three to four times as numerous in the medulla as in the cortex of the adenohypophyses. No breed differences were seen between sixteen Friesian and sixteen Ayrshire bull calves or between ten Grade and ten Masai Boran bulls.

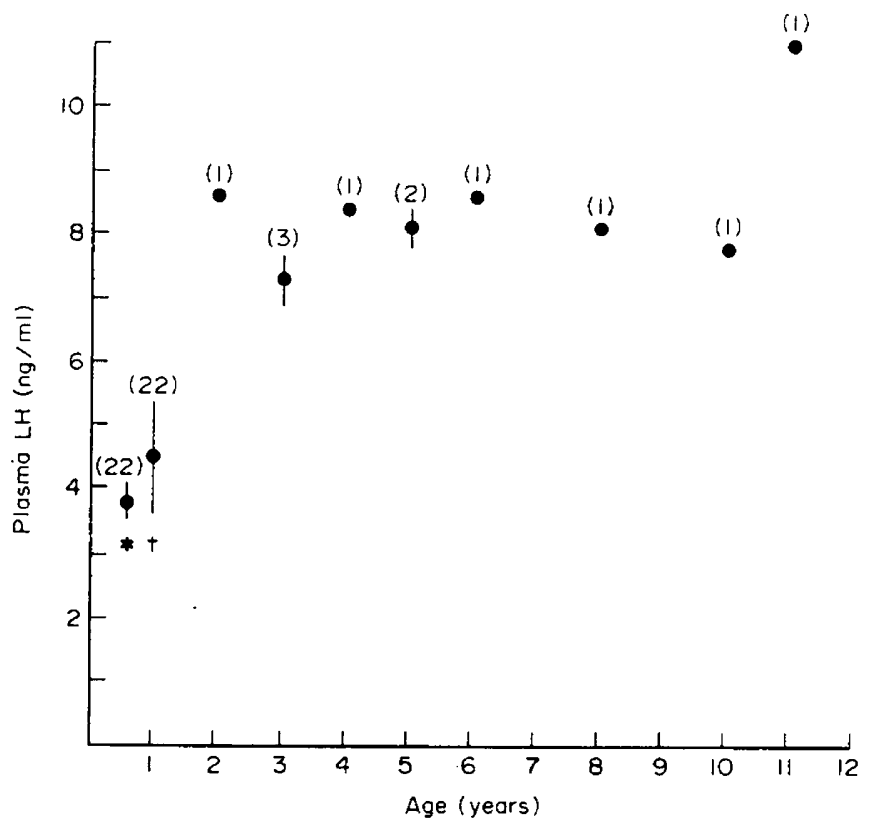

TEXT-FIG. 1. Variation of plasma LH levels with age in Holstein and Angus bulls. Mean \pm S.E.M.* Angus bulls 7 to 9 months old. $\dagger$ Angus bulls 12 to 14 months old. Number of animals in each group is given in parentheses.

At 7 to 9 months, all Angus bulls had measurable plasma $\mathrm{LH}$ values. The mean value was $3.7 \pm 0.3 \mathrm{ng} / \mathrm{ml}$ at the beginning of the experiment and the minimum value was $1.8 \mathrm{ng} / \mathrm{ml}$. By 12 to 14 months, the mean basal LH value had risen to $4 \cdot 3 \pm 1 \cdot 1 \mathrm{ng} / \mathrm{ml}$. Most of the twenty-two bulls examined, however, had irregularly occurring $\mathrm{LH}$ peaks which were three to four times the basal value. Text-figure 1 shows that adult values of 7 to $10 \mathrm{ng} / \mathrm{ml}$ are probably obtained by 2 years, and that, thereafter, basal values remain fairly constant. It should be noted that the values for bulls over 2 years of age represent individual samples 

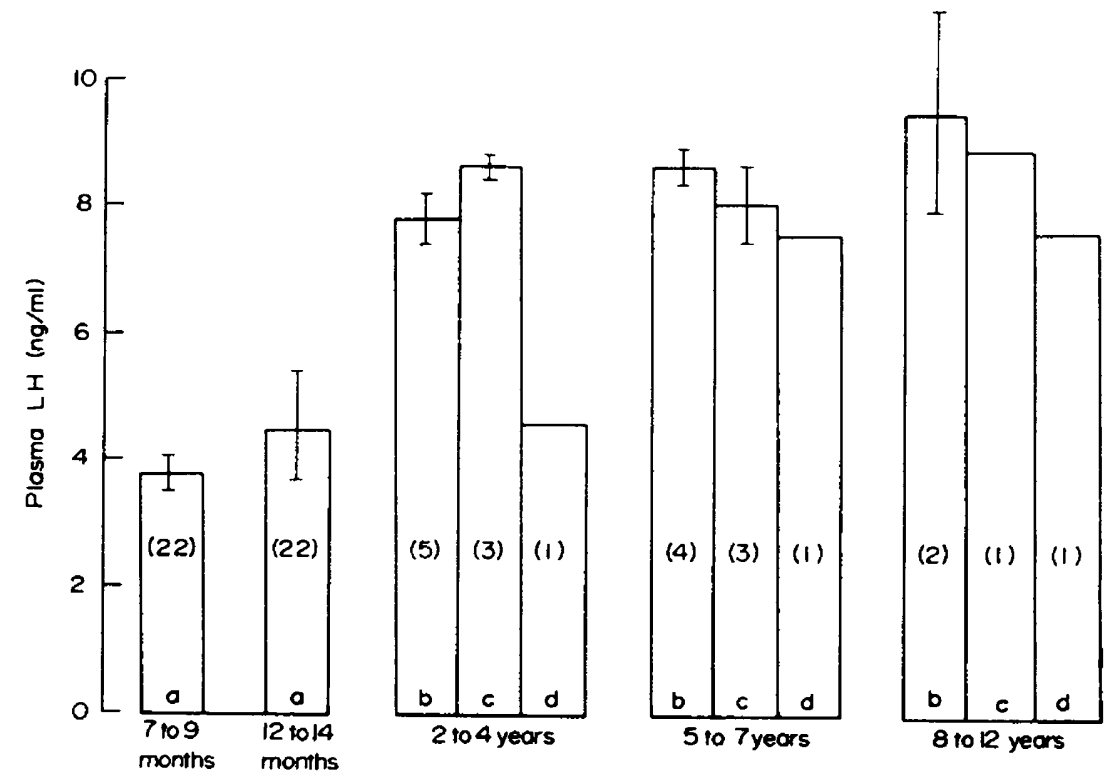

TExT-FIG. 2. Influence of breed of bull on plasma LH levels. Mean \pm S.E.M. a = Angus; $b=$ Holstein; $c=$ Guernsey; $d=$ Jersey. Number of bulls in each group is given in parentheses.

collected on one occasion and they all belong to Holstein bulls. However, daily values obtained from three 6-year-old Holsteins for two periods of 1 month each were similar (Text-fig. 4).

\section{Influence of breed}

Comparisons of plasma LH levels for the eleven Holsteins and seven Guernsey

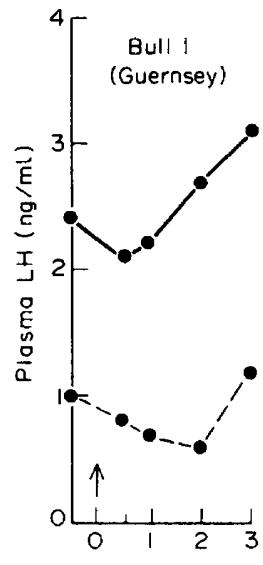

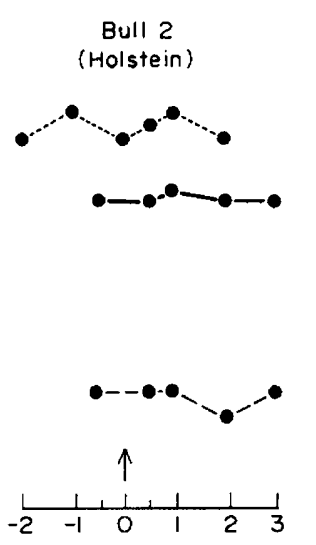

Time before and offer teosing and ejoculation ( $h r$ )
Bull 3

(Holstein)
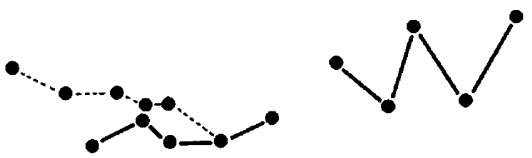

Bull 4

(Guernsey)

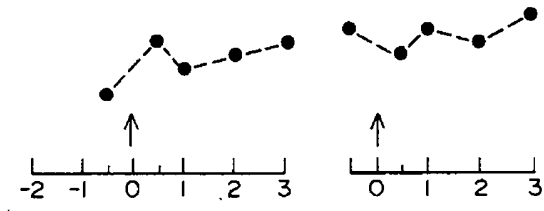

TExT-FIG. 3. Influence of teasing and ejaculation on plasma LH values in Holstein and Guernsey bulls aged $1 \frac{1}{2}$ to 2 years. $-\bullet$, Teasing with a bull, 18th June 1971; $-\ldots$ teasing with a bull, 22nd June $1971 ; 0 . . .0$, teasing with an oestrous cow, 13th August 1971 ; $\uparrow$, point of teasing. 
bulls aged 2 to 12 years revealed no differences between these two breeds. Both had a range of plasma $\mathrm{LH}$ values of 7 to $10 \mathrm{ng} / \mathrm{ml}$ (Text-fig. 2). The plasma $\mathrm{LH}$ values of the three Jerseys examined were also in the same range but the paucity of the numbers precludes meaningful comparison. The values of the young Angus bulls are included in the Text-figure, even though values from other breeds of similar age were not available for comparison.

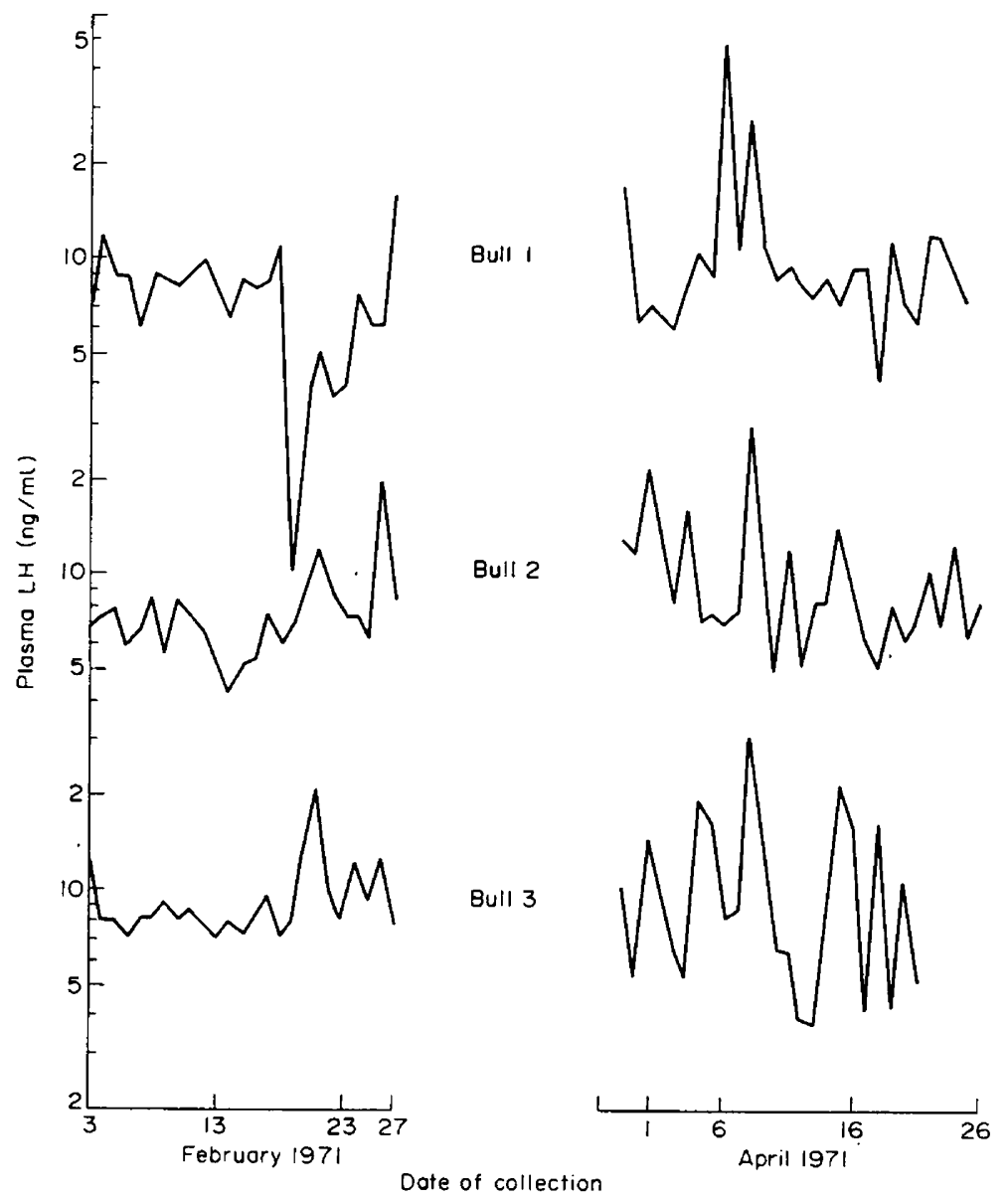

TEXT-FIG. 4. Daily fluctuations in plasma LH values in three 6-year-old Holstein bulls.

\section{Influence of sexual stimulation}

In three of the four bulls examined, there was a slight decrease in plasma $\mathrm{LH}$ levels $\frac{1}{2} \mathrm{hr}$ after teasing and ejaculation; in only one of the four bulls was there a slight, non-significant increase. This pattern was the same on the two occasions when a teaser bull was used and the one occasion when two of the experimental bulls were teased with an oestrous cow. In all cases, the fluctuations in plasma $\mathrm{LH}$ values over experimental periods of 3 to $4 \mathrm{hr}$ was slight and never exceeded $1 \mathrm{ng} / \mathrm{ml}$. The pattern of fluctuations, however, was very similar for individual 
bulls on the two or three separate occasions that they were examined (see Text-fig. 3).

\section{Temporal variation in plasma $\mathrm{LH}$ levels}

It has already been mentioned that $\mathrm{LH}$ peaks of 12 to $16 \mathrm{ng} / \mathrm{ml}$ were frequently found in plasma samples from yearling Angus bulls bled every 2 weeks for 5 months. These peaks were three to four times the basal values of the young bulls.

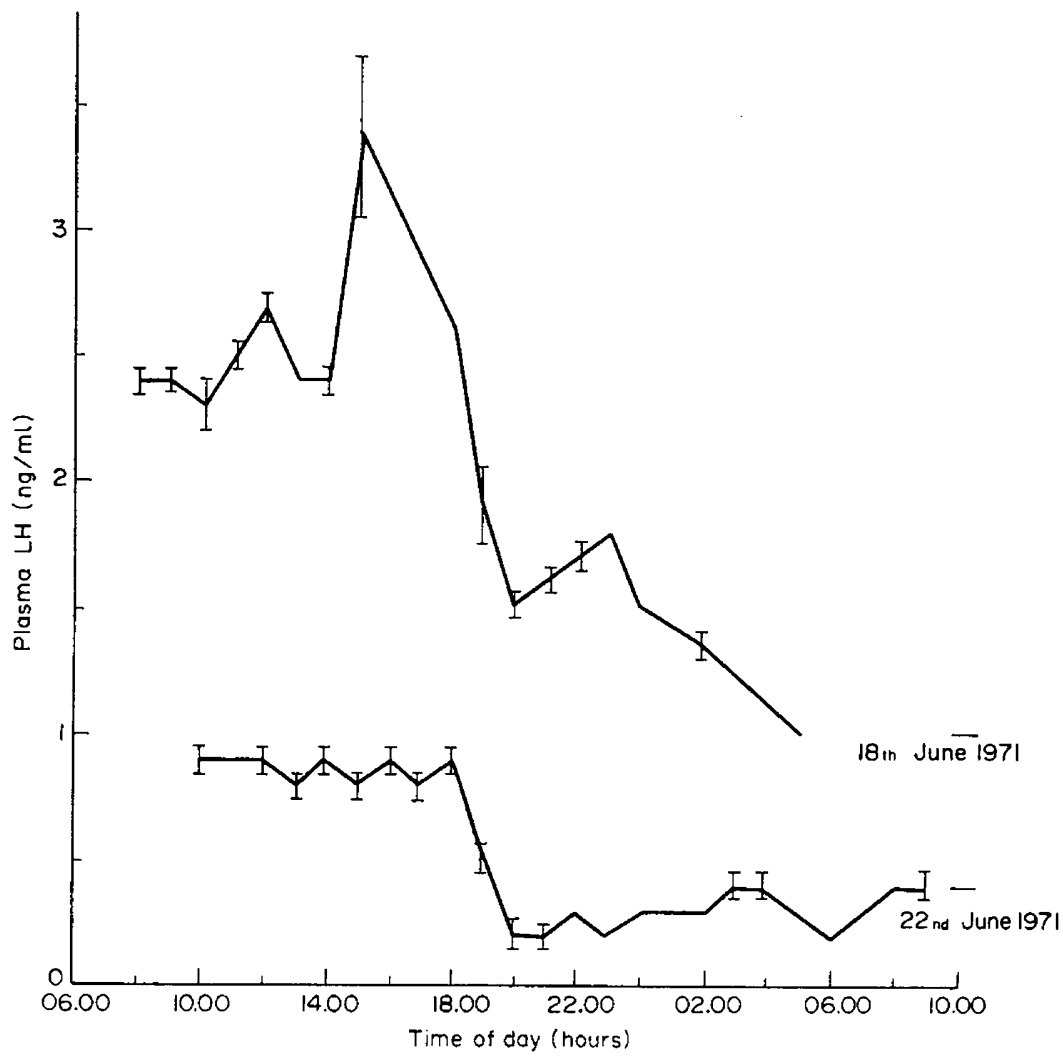

TeXT-FIG. 5. Variation over $24 \mathrm{hr}$ in plasma LH levels of two Holstein and two Guernsey bulls aged $1 \frac{1}{2}$ to 2 years. Mean + S.E.M. Blood collection was started at 07.00 hours and 10.00 hours on 18 th June and 22 nd June, respectively.

When daily values of three 6-year-old Holsteins were determined for two periods of 1 month each, it became evident that daily fluctuations in plasma LH values were erratic. The basal range for the three bulls was of the order of 7 to 10 $\mathrm{ng} / \mathrm{ml}$ but peaks of 20 to $50 \mathrm{ng} / \mathrm{ml}$ were not infrequent (see Text-fig. 4). Conversely, low values near the limit of detection were also recorded.

A surprising feature in these fluctuations was that the $\mathrm{LH}$ peaks and troughs tended to coincide in all animals on the same days. In other words, on days when plasma $\mathrm{LH}$ values were high, they were high in all animals and vice 
versa. This was also seen on the two occasions when young bulls were examined for the influence of sexual stimulation (Text-fig. 3) and circadian variation (Text-fig. 5).

Clear differences were found between the diurnal and nocturnal plasma $\mathrm{LH}$ values in the two Holsteins and two Guernseys bled every hour for $24 \mathrm{hr}$ on two separate occasions. The values were high between late morning and early afternoon. There was a precipitous decrease at 18.00 hours which coincided with the closing down of the barn, at which time most of the bulls would be lying down. Nocturnal values remained low (less than half the diurnal values) until the animals were fed the following morning. It will be noted from Text-fig. 5 that, while the 24-hr pattern was similar on the two occasions, the actual plasma LH values were higher on one occasion. The standard errors of the means were small.

On two other occasions, when blood samples were taken from the same bulls every $10 \mathrm{~min}$, it became evident that hourly fluctuations were insignificant. In Text-fig. 6 , it would appear that increases from 07.00 to 08.00 hours were
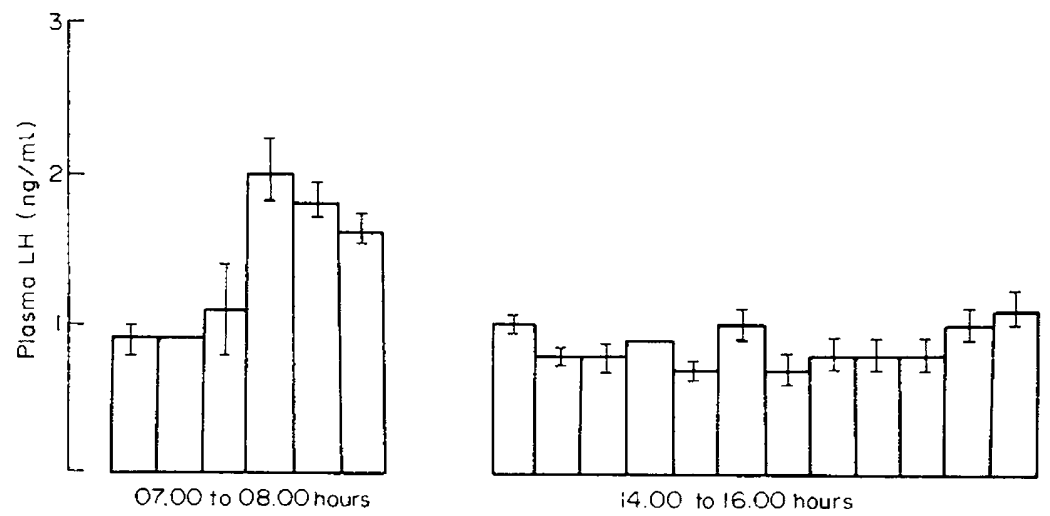

Text-FIG. 6. Hourly fluctuation in plasma LH values in four bulls (two Holsteins and two Guernseys) aged $1 \frac{1}{2}$ to 2 years. Blood samples collected every $10 \mathrm{~min}$ by jugular venipuncture. Each histogram represents the mean value for the four animals \pm S.E.M.

significant. This, however, could be due to a change-over from low nocturnal values to high diurnal values. Values obtained from 14.00 to 16.00 hours showed fluctuations of no more than $\pm 0.3 \mathrm{ng} / \mathrm{ml}$.

\section{DISGUSSION}

\section{Influence of age}

Buckler \& Clayton (1971) found high plasma LH values within the first 6 months of age in boys and girls. Thereafter, the $\mathrm{LH}$ levels declined to low values until the age of 6 years when steady increases in plasma LH occurred until puberty was reached. In rats, pituitary LH concentration has been reported (Ramirez \& Sawyer, 1965) to be maximal before puberty, at 20 days of age. An analogous maximal pituitary concentration of prolactin was found 
by Sinha \& Tucker (1970) in 3-month-old heifers. Thus, there appears to be a build-up of pituitary trophic hormones before their release into the circulation. The appearance of $\mathbf{L H}$ in the plasma of boys and girls at 6 years of age, when no delta cells can be demonstrated in the adenohypophyses by the PASOrange G-staining technique, can now be attributed to the shortcomings of this method. In bulls, Simmons et al. (1970) showed that delta cells, which appeared to be devoid of LH when stained by PAS-Orange G, had considerable LH when stained by the fluorescent antibody technique. The PAS-Orange $\mathrm{G}$ procedure was found to be more closely related to the granularity of the cells. We noted in bulls that the delta cell granules increased in size and number with age concomitant with an increase in intensity of staining with PAS-Orange G.

A slow continual secretion of gonadotrophins appears to occur before puberty with a spurt in production as puberty is approached. In boys and girls, Sizonenko et al. $(1969,1970)$ found this accelerated increase between 9 and 11 years. Bratton, Musgrave, Dunn \& Foote (1959) determined the age of puberty of the Holstein bull as 11 months. More recently, Hahn \& Krause (1969) have demonstrated the presence of mature spermatocytes in the testes of a Holstein-Friesian bull at 7 months and have advanced the opinion that puberty occurs at 7 to 9 months in this breed depending on the level of nutrition.

We found that delta cells occur in well fed calves as early as 1 month of age. We also found that the delta cell population of poorly nourished Boran bulls aged $1 \frac{1}{2}$ years was not different from a well-nourished calf of 2 months. After 3 years of age, all bulls had similar delta cell populations irrespective of the state of nutrition.

We found considerable quantities of LH in the plasma of 7-month-old well-fed bulls. Both these observations parallel the pattern of gonadotrophic activity in boys and girls. Similar gradual changes in androstenedione/testosterone ratios have been reported in bulls between the ages of 4 months and maturity by Skinner, Mann \& Rowson (1968). It would seem, therefore, that hormonal changes leading to puberty start early, and are gradual, rather than sudden.

\section{Influence of breed}

Although no differences were found in plasma LH values between the Holstein and Guernsey bulls examined, the paucity of numbers makes it necessary to regard the LH values with caution. It should be pointed out, however, that the significantly higher incidence of testicular tumours in Guernsey bulls need not necessarily be due to the higher LH concentrations in the plasma of this breed. No one has determined the amount of LH or the pattern of LH secretion necessary to maintain these tumours. The apparent absence of any cytological differences between the delta cell population of Friesian and Ayrshire calves or between the Grade and Masai Borans might be taken as a further indication that breed differences in gonadotrophic activities are slight, if they exist.

\section{Influence of sexual stimulation}

Katongole et al. (1971) showed a convincing reciprocal relationship between plasma LH and testosterone levels in two 8-year-old Friesian bulls. Their figures indicated that there were large fluctuations in LH levels even before the 
animals were teased. This makes it uncertain that the purported increase in plasma LH levels they observed in one bull, on two occasions, within $30 \mathrm{~min}$ of being teased by an oestrous cow, was due to sexual stimulation. Convey, Bretschneider, Hafs \& Oxender (1971) found a small $(<0.2 \mathrm{ng} / \mathrm{ml})$ nonsignificant increase in twelve dairy bulls (one Jersey and eleven Holstein) aged $1 \frac{1}{2}$ to 6 years within $5 \mathrm{~min}$ of sexual preparation. After $30 \mathrm{~min}$, the plasma LH levels were not different from the prestimulation values. The patterns of LH release in the four young bulls we examined were remarkably similar for individual bulls on all occasions, whether they were teased with an oestrous cow or another bull. There was not, however, any increase in plasma LH that occurred within 30 min of teasing or later that could be attributed to sexual stimulation of the animals. It would seem, therefore, that either a surge in plasma LH in bulls following sexual stimulation is small and occurs between 5 and 30 min after ejaculation, or that the half-life of LH in bulls is very short.

\section{Temporal fuctuations}

In the mature Friesian bulls examined by Katongole et al. (1971), fluctuations of 0 to $400 \mathrm{ng} / \mathrm{ml}$ were recorded. From our results, it is evident that large daily fluctuations in plasma $\mathrm{LH}$ values occur. Values of 0 to $50 \mathrm{ng} / \mathrm{ml}$ were recorded in 6-year-old Holstein bulls over two periods of 1 month each. No cyclic pattern was seen. The circadian concurrence of $\mathrm{LH}$ peaks and troughs in the bulls would suggest some common external influence on LH secretion, as yet undetermined. Since the sera over a collection period of 1 month were all assayed about the same time, it is improbable that the concurrence of LH peaks are attributable to assay differences.

The presence of temporal variation was clearly seen on the 2 separate days on which hourly blood samples were taken for $24 \mathrm{hr}$. The diurnal values were twice as high as the nocturnal values and the change-over was abrupt, coinciding with the resting of the animals when their barn was shut at about 18.00 hours. The 24-hr variation reported here for bulls is much more evident than similar changes in Holstein cows reported by Wilks \& Hansel (1971) who found increases of less than $25 \%$ between early morning ( 09.30 hours) and late afternoon ( 17.00 hours) values (from $1.65 \mathrm{ng} / \mathrm{ml}$ to $2.02 \mathrm{ng} / \mathrm{ml}$, respectively). In our studies, the diurnal values were greater than the nocturnal values by over $50 \%$ and amounted to $>1.10 \mathrm{ng} / \mathrm{ml}$ on the one occasion when the basal values were generally high and $>0.50 \mathrm{ng} / \mathrm{ml}$ on the other occasion when the basal values were generally low (Text-fig. 5).

Plasma samples taken by jugular venepuncture every $10 \mathrm{~min}$ showed that hourly variations during the day-time were slight and non-significant for the young Holstein and Guernsey bulls examined.

\section{REFERENCES}

Bratton, R. W., Musgrave, S. D., Dunn, H. O. \& Foote, R. H. (1959) Causes and prevention of reproductive failures in dairy cattle. Influence of underfeeding and overfeeding from birth to 80 weeks of age on growth, sexual development and semen production of Holstein bulls. Bull. Cornell Univ. agric. Exp. Stn, 940.

BuCKLER, J. M. H. \& Clayton, B. E. (1971) Output of luteinizing hormone in urine of normal children and those with advanced sexual development. Archs Dis. Childh. 45, 478. 
Burr, I. M., Sizonenko, P. C., Kaplan, S. L. \& Grumbach, M. M. (1970) Hormonal changes in puberty. Correlation of serum luteinizing hormone, follicle stimulating hormone with stages of puberty, testicular size and bone age in normal boys. Pediat. Res. 4, 25.

Convey, E. M., Bretschneider, E., Hafs, H. D. \& Oxender, W. D. (1971) Serum levels of LH, prolactin and growth hormone after ejaculation in bulls. Biol. Reprod. 5, 20.

DunN, H. O. \& McENTEE, K. (1964) Semen quality and fertility in dairy bulls with testicular tumours. Int. F. Fert. 9, 613.

Hahn, J. \& Krause, D. (1969) The onset of puberty in a young bull. Dt. tierärztl. Wschr. 76(a), 241.

Honson, W. C. \& Hansel, W. (1972) Plasma LH levels after ovariectomy, corpora lutea removal and estradiol administration in cattle. Endocrinology, 91, 185.

Jubs, K. V. \& McEnTEE, K. (1955) Observations on the bovine pituitary gland. II. Architecture and cytology with special reference to basophil cell function. Part of doctoral thesis, Cornell University.

Katongole, C. B., NAftolin, F. \& Short, R. V. (1971) Relationship between blood levels of luteinizing hormone and testosterone in bulls, and the effects of sexual stimulation. F. Endocr. 50, 457.

Pichurova, K. M. (1970) Features specific to the excretion of gonadotrophic hormones during puberty. Akush. Ginek. 46, 12.

Ramirez, V. D. \& SAWYer, G. H. (1965) Advancement of puberty in the female rat. Endocrinology, 76, 1158.

Simmons, K. R., Cochrane, D. E. \& Pomerantz, D. K. (1970) Bovine pituitary cytology and source of LH. 7. Anim. Sci. 30, 73.

Sinha, Y. N. \& Tucker, H. A. (1970) Mammary development and pituitary prolactin levels of heifers from birth through puberty and during the estrous cycle. F. Dairy Sci. 52, 507.

Sizonenko, P. C., Burr, I. M., Kaplan, S. L. \& Grumbach, M. M. (1969) Serum gonadotrophins in normal prepubertal children and during puberty. Annls Endocr. 30, 702.

Sizonenko, P. C., Burr, I. M., Kaplan, S. L. \& Grumbach, M. M. (1970) Hormonal changes in puberty. II. Correlation of serum luteinizing hormone and follicle stimulating hormone with stages of puberty and bone age in girls. Pediat. Res. 4, 36.

Skinner, J. D., Mann, T. \& Rowson, L. E. A. (1968) Androstenedione in relation to puberty and growth of the male calf. $\mathcal{F}$. Endocr. 40, 261.

Swanson, H. E. \& Ezrin, C. (1960) The natural history of delta cells of the human adenohypophysis in childhood, adulthood and pregnancy. F. clin. Endocr. Metab. 20, 952.

Wilks, J. W. \& Hansel, W. (1971) Oxytocin and the secretion of luteinizing hormone in cattle. $\mathcal{J}$. Anim. Sci. 33, 1048.

YEN, S. G. G. \& Vrcic, W. J. (1970) Gonadotropin levels in puberty. I. Serum luteinizing hormone. Am. F. Obstet. Gynec. 106, 134. 